\title{
THE ROLE OF AUTOMATIC TICKETING SYSTEM IN PROVIDING SERVICE QUALITY TO PASSENGERS
}

\author{
Erika Chairunnisa $^{1}$, Chrisna Jaka Rahmawan ${ }^{2}$, Lies Lesmini ${ }^{3}$ \\ Prima Widiyanto ${ }^{4}$ \\ 1. STMT Trisakti, 2. STMT Trisakti, 3. STMT Trisakti, 4.STMT Trisakti \\ Corresponding author: erika.chairunnisa07@gmail.com
}

\begin{abstract}
The purpose of this research is to identify deeply on how Automatic Ticketing System can assist the flow of passengers and vehicles in the Port of Merak to the Port of Bakauheni smoothly. In this case, the automatic ticketing system has made the movement of passengers from the port of Merak to the port of Bakauheni easier. The method of this research is quantitative descriptive. The data was collected through questionnaire and interview. This research was conducted at PT. Angkutan Sungai Danau dan Penyebrangan Indonesian Ferry Merak Branch, Cilegon, Banten. PT. ASDP is one of the state-owned enterprises in Indonesia which is dealt with freight and ferry port services for passengers and vehicles. Variable (X) used in this research is divided into three variables;Easiness (X1), Facilities (X2), Service (X3), and variable $(\mathrm{Y})$ is Customer Satisfaction. The population of this study were all passengers and vehicles that use crossing services at Merak port. Samples were taken using Random Sampling technique, which took a total sample of 100 respondents. The result of this research is that service quality has a significant influence towards customers' satisfaction within the output value of $\mathrm{R}$ square equal to 0,596. It means that variable $\mathrm{X} 1, \mathrm{X} 2$ and $\mathrm{X} 3$ have simultaneously influenced $\mathrm{Y}$ variable, which is equal to $59,6 \%$.
\end{abstract}

Keywords: Service Quality, Easiness, Facilities, Service, ASDP Merak Branch, Customer Satisfaction.

\section{Introduction}

Competition among transportation businesses especially in sea crossing transportation is very tough from time to time. Even in this globalization era, many companies are competing to provide services to pamper transportation usersand display their advantages. Continuous excess is a requirement to keep the company in good and stable position (Lesmini, Purwanto, \& Trisakti, 2016). PT Angkutan Sungai Danau dan Penyebrangan (ASDP) Merak branch,one of the companies which is dealt with crossing of passengers and vehicles, use a manual system in which passengers use conventional tickets in the form of paper to cross from the Port of Merak to the Port of Bakauheni. The use of the manual system has led to a long queue of passengers at both booths, and vehicles in the toll gate.Thus,because of the long queue time, many brokers take this opportunity to resell conventional tickets at higher 
price. This condition has caused inefficiencies in terms of cost and time. To maximize the quality of service to the community, PT. ASDP presents a program called Automatic Ticketing System (ATS) based on Radio Frequency Identification (RFID) technology to facilitate passengers to purchase crossing tickets from Merak Port to Bakauheni Port. According to Davis F.D (1989) the easiness use of ATS can create a trust from passengers since it can assist them in doing their business.

The quality of a service can usually be measured by identifying the level of the service quality that can meet expectations of service users.The level quality of service should be submitted to the user on an ongoing basis. Quality of service is impracticableand difficult to understand (Parasuraman, A., Zeithaml, V., \& Malhorta, n.d.).The service quality supposed to match between what customers feel and what company serves by its performance. Meanwhile, according to Kotler, P\& Keller(2011) the definition of service quality is when customers have achieved what they need throughmaximum service served by the company. Service quality is very important to create customers' satisfaction. The more quality the services provided by the company, the higher the customers' satisfaction. According to Zeithaml, and Valarie A. Bitner (2003) satisfaction is an assessment of a product or service by providing a positive value of consumption. So customers' satisfaction is the customer's feelings when the customer's service met or exceeded what customers expect (Yeo, Thai, \& Roh, 2015). Similarly, in terms of services provided, the company should be able to generate customers' satisfaction in order to establish a good relationship between customers and companies (Thamrin, n.d.).

ATS (Automatic Ticketing System) is one of the facilities in accordance to the consumers' expectation, that can help the economic process run well and ultimately to facilitate the community in meeting their needs (Simarmata \& Keke, 2017). The definition of facilities according to Yazid (2005: 136) is physical evidence in the form of objects or goods to support a service. The point is good service can also be determined by good infrastructure that can accommodate the needs of customers(S, n.d.). Service is an activity that does 
not materialize but must be felt by every customer who use the crossing service at the Port of ASDP Merak.Of course the level of service will always be perceived by each passenger service users and can find out how customers enjoy the service or not. The quality of a service is a measure of good or bad circumstances offered by the company (Saribanon et al., 2016). According to (Plessis, P. J., \& Rousseau, 2003) services are intangible activities but provide a sense of satisfaction that should not necessarily be related to product sales.Satisfying the needs of consumers is the desire of every company. In addition to the important factors for the benefit of our lives, satisfying the needs of consumers can enhance excellence in competition. Customers' satisfaction will give a good influence for the company because it can create customers' loyalty (Darunanto, n.d.).

\section{Method}

This research uses Quantitative Descriptive method that the implementation is conducted through: survey technique and case study (different from one case). This research is conducted at Merak crossing port, in Cilegon Banten. The data sources or research subjects in this study were passengers and some employees of PT. ASDP in accordance with the needs of this study. There are 100 respondents. While Data Analysis Technique used in this research was Descriptive Analysis which is used to analyze responders' responses towards Service Quality and Satisfaction and responsiveness to dependent variable, customers' satisfaction.Partial test (T Test) was conducted to identify the partialinfluence of independent variables consisting of reliability, security, physical evidence, empathy and responsiveness towards the dependent variable of customer satisfaction. In addition, Determination Coefficient Analysis (R2) was used to measure how far does the ability of the model explain the variation of the dependent variable (customer satisfaction). The coefficient of determination is between zero and one. Small coefficient of determination means that the ability of independent variables (service quality) in explaining the variation of dependent variable (customer satisfaction) is very limited. The value of coefficient determination was approaching one. It 
means that independent variables (service quality) provide almost all information needed to predict the variation of dependent variable (customer satisfaction). The population in this study were customers who use thecrossing service at the Port of ASDP Merak Branch which is still active in the period of 30 October 2017 to 5 November 2017 in which the number of 100 customers in the can. With the additional data provided by the company in sufficient detail ranging from passengers data to vehicle data crossing through the Port of Merak. The additional data used to support this research is the data of passengers and vehicles in January to December 2016. With the number of service users is $3,610,314$ consisting of 1,569,240 passengers and 2,041,074 vehicles, sampel determination using sovlin formula.The formula has been obtained sampel of 100 respondents.

\section{Result and Discussion}

\section{Concept of ATS (Automtic Ticketing System).}

Automatic Ticketing System is a system that serves to replace conventional tickets into an automated ticket. The application of ATS is to eliminate the possibility of losses that are still experienced by both consumers and crossing ship operators. The ATS is completely accurate in recording the identity of the passenger and measuring the type of vehicle dimensions as well as the items to be included in the ship's loading manifest. This Manifest is important for service users as it is part of the insurance document for passengers and cargo ship. By the old system, inaccuracies potentially occurred during the identification of passengers and vehicles. It might cause lower or higher tariffs than the class set by the government. The condition is eventually disadvantageous for service users or ship owners. By the Automtic Ticketing System, both service users and ship operators will get the benefit since the trans-ferry tariff transaction will actually refer to the government regulation set forth in Permenhub No 63 of 2015 on Inter-Cross Crossing Tariff Rules of the Province. For ship operators, the implementation of this system will also reduce potential leakage and increase revenue. The difference of the previous ticketing system with ATS, lies in automatic vehicle group 
determination. Sensors are alreadyautomatically installed in tollgate to detect the type of vehicle class. The photograph of the vehicles, the driver's name even the vehicles' license plate can be recorded by the sensor.The system is easier and gives more advantageous for the parties who need such data,for example the police.

\section{The movement of passengers at the Port of Merak Bakauheni.}

Although using conventional tickets, passengers who pass through Merak Port to Sumatra Islandincrease every year. Conventional ticket has some weaknesses that make the process of crossing becomes less effective.Passengers spend longer time in queueing. To improve services to passengers especially on the ticket system PT.ASDP modernize tickets to be automatic based that can facilitate the process of crossing for passengers.Moreover, it can also ease the process of manifesting data of the passengers and vehicles. The presence of the application of ATS increase the number of passengerssignificantly compared to the use of conventional tickets (paper tickets).This automatic ticket makesthe process of purchasing tickets and entering the vessel easier and faster for the passengers.

\section{Use of ATS in reducing waiting times and costs.}

The use of ATS gives a lot of advantages for passengers and also for vehicle users who use the facility of crossing port of Merak. ATS or electronic ticket can minimize the cost due to the short time access passengers and vehicles entering the port. Even for the ships, the cost of waiting for the passengers is decreased now. Automatic Ticketing System can decrease the queue time of passengers. After registration and data collection, the ticket is activated at the counter and the vehicles on tollgate have an easy access provided by the company. Passengers only need to stamp the ticket on the machine provided then directly enter the ship accordingly with the guidance of the officers in the field.Automatic Ticketing System is applied as a solution made by PT.ASDP Indonesia Ferry Branch Merak, which offers various benefits, and convenience that felt by passengers or vehicles users. 


\section{The ease of use.}

Based on the result of data processing, it was identified that the respondents' perception about ease of use was equal to $88,5 \%$. It shows that most of the respondents agreed that the ASDP Port Merak creates convenience that passengers can feel directly. In this point, customers gave sincere feedback that the new system provides the service well and wholeheartedly and it has definite steps.

\section{Facilities.}

From the result of data processing, it was identified that respondent perception toward sub variable of facility is equal to $86,9 \%$. Most respondents strongly stated that they do agree with the facilities provided and served by ASDP in which Merak Port gives excellent benefits for passengers. Existing facilities can also support all the needs, even provide a sense of security for the passengers and users of motor vehicles who cross from the port of Merak to the Port of Bakauheni. Meanwhile, the perception of respondents toward sub variable empathy is equal to $87,6 \%$. Most respondents agreed that ASDP Peacemak employees provide and present personalizedattention to their customers. The number of ships is adequate fulfilled with safety standards and the security is good enough.The employees also givemore attention to the customers. They seem to understand the needs of their customers.

\section{Overall Service Quality.}

Responses from respondents regarding the quality of service as a whole are excellent either in particular through electronic tickets or in terms of other facilities.It can be seen that the percentage of the total average of all Subvariables Quality of Service reached $87.66 \%$.

\section{Customer satisfaction.}

The perception of respondents related to Customer Satisfaction was $90.80 \%$. In this case the results indicate that most respondents stated that they strongly agree with ASDP Merak Port which presents services in accordance with the wishes and needs of customers of crossing service users. The quality of servicefrom ASDP at Merak port is believed to be better compared to other ports. It is proven by the limited complaints given by customers 


\section{Discussion}

Based on descriptive analysis, the majority of respondents express strongly agree with the Port ASDP Merakboth in service or electronic tickets and in terms of other facilities. The total average of all Sub variables Quality of service reached $87.66 \%$. This may indicate that the overall service quality of the Peak ASB Peels is good enough.Related to the testing Hypothesis using table $\mathrm{t}$ was identified as sig value. For the effect of $\mathrm{X} 1$ to $\mathrm{Y}$ is equal to 0.002 $<0.1$ and the value of $t$ count 3.199> $t$ table 1.660 , so it can be concluded that $\mathrm{H} 1$ is accepted.It means there is an influence of $\mathrm{X} 1$ to Y.There is also an influence of Ease of use of electronic ticket towards customer satisfaction that the precentage is $88.5 \%$.For the effect of $\mathrm{X} 2$ to $\mathrm{Y}$ is equal to $0.62<0.1$ and the value of $\mathrm{t}$ arithmetic $1.891>1.660$, so it can be concluded that $\mathrm{H} 2$ is accepted. It means X2 influences Y.In this case,it is proven that Automatic Ticketing System is a very helpful facility for purchasing the tickets and it is also easy to use. Theeffect of Customer Satisfaction percentage is $86,9 \%$. It can be seen again in sig value. For the influence of $\mathrm{X} 3$ to $\mathrm{Y}$ is $0,000<0.1$ and the value of $t$ count $3.708>1.660$, so it can be concluded that $\mathrm{H} 3$ is accepted.It means X3 influences $\mathrm{Y}$ which related to Services provided by the company.The application of Automatic Ticketing System is in accordance with the customers' needs and service expectation. The results indicated the level of service has had a positive and significant impact on Customer Satisfaction, and the percentage is $87.6 \%$. Hypothesis Testing with F test based on the outputs of significance for the effect of X1, X2 and X3 simultaneously to $\mathrm{Y}$ is $0.000<0.1 \mathrm{~F}$ value count $47.231>\mathrm{F}$ table 2.14 , so it can be concluded that $\mathrm{H} 4$ is accepted.It means $\mathrm{X} 1, \mathrm{X} 1$ and $\mathrm{X} 3$ simultaneously influence Y.There is simultaneous influence related to Automatic Ticketing System through variable Ease of Use, Facilities and Service to Customer Satisfaction of ASDP Merak Port.

In this research, some respondents expressed and strongly agreed that Merak Port presents a service, which meets the customers' needs and quality expectation. ASDP Merakis said to be better than the other crossing companies. Moreover, it is proven by the limited complaints given by the 
customers. The percentage of ASDP Merak Branch in this case is $90.8 \%$. It can be concluded that the level of customer satisfaction related to the application of ATS is very good. Based on the results of this research, it showsthat the variable of Ease of Use and Service variable have dominant influences on Customer satisfaction compared to other variables. The Ease of Use variable has a positive and high influence, while Facilities and Service factors have positive influence but not significant.

\section{Conclusion}

According to the results of the research conducted, conclusions drawn are as follows;

1. Service Quality of Port of ASDP in Merak Branch

Based on the result of the descriptive analysis of service quality at ASDP Merak Branch, the company has got positive appraisal and good impression from the customers.

2. Customer Satisfaction on ASDP Merak branch

Based on the results of descriptive analysis of customer satisfaction of ASDP,The customers are satisfied by the presence of ATS because it facilitates them in purchasing the tickets and in entering the vessels. It can be concluded that customers will faithfully use the service of this Merak Port crossing again.

3. Partial Service Quality Impact

According to $t$ test results, it can be concluded:

- Ease of use partially significant or high enough to customer satisfaction of Merak Port.

- Facilities partially have a significant or significant impact on Customer Satisfaction of Merak Port.

- Partial service has a significant or significant influence on Customer Satisfaction of Merak Port Customer.

4. Effect of Service Quality Simultaneously On Customer Satisfaction at ASDP Merak Branch 
Based on the results of the F Test, it can indicated that Service Quality has a high or significant influence on customers' Satisfaction. In this case, the Ease of Use Variables, Facilities and Service give simultaneously significant effect on Customer Satisfaction.

\section{References}

Darunanto, D. (N.D.). Layanan Terhadap Kepuasan Pelanggan Pt . Dms Tour And Travel, 201-219.

Kotler, P, Keller, K. L. (2011). Marketing Management (14th Ed.). Pearson.

Lesmini, L., Purwanto, B., \& Trisakti, S. (2016). Ekonomi Maritim \& Sumber Daya Manusia Indonesia. Jurnal Manajemen Bisnis Transportasi Dan Logistik, 2(3), 372-389. Retrieved From Http://Library.StmtTrisakti.Ac.Id/Jurnal/Index.Php/JMBTL/Article/View/65

Parasuraman, A., Zeithaml, V., \& Malhorta, A. (N.D.). A Multiple -Item Scale For Assessing Electronic Service Quality, 7(3), 213-233. Https://Doi.Org/1094670504271156

Plessis, P. J., \& Rousseau, G. G. (2003). Buyer Behaviour: A Multi-Cultural Approach. Oxford University Press Southern Africa.

S, T. I. H. (N.D.). Multimoda Dalam Mewujudkan Visi Logistik Indonesia 2025, 69-84.

Saribanon, E., Manajemen, S. T., Trisakti, T., Sitanggang, R., Manajemen, S. T., \& Trisakti, T. (2016). Kepuasan Pengguna Jasa Transportasi The Satisfaction Of Transportation' S, 3(3), 317-326.

Simarmata, J., \& Keke, Y. (2017). The Influence Of Travel Agent, Infrastructure And Accommodation On Tourist Satisfaction, 28(Ictgtd 2016), 281-283.

Thamrin, M. (N.D.). Kualitas Pelayanan Jasa Keagenan Kapal Dan Komunikasi Interpersonal Pada Services Quality Of Ship Agency Services And Interpersonal Communication In Shipping Companies, $3(2), 217-225$.

Yeo, G. T., Thai, V. V., \& Roh, S. Y. (2015). An Analysis Of Port Service Quality And Customer Satisfaction: The Case Of Korean Container Ports. Asian Journal Of Shipping And Logistics, 31(4), 437-447. Https://Doi.Org/10.1016/J.Ajs1.2016.01.002

Zeithaml, Valarie A. Bitner, M. J. (2003). Services Marketing: Integrating Customer Focus Across The Firm. Australia: Boston: Mcgraw-Hill/ Irwin, (C2003.

Davis, F. D. (1989). Perceived Usefulness, Perceived Ease Of Use, And Acceptance Of Information System Technology. MIS Quarterly, Vol.13, No.3, Pp 319-340

Yazid. 2005. Pemasaran Jasa. Edisi Kedua. Cetakan Pertama, Ekononisia, Yogyakarta. 